Original Research Article

\title{
Knowledge and perception towards pharmacovigilance and adverse drug reactions reporting among medical students at a teaching hospital in South India
}

\author{
Akshay J. K., Hemanth Kumar K. H.*
}

Department of Pharmacology, Mysore Medical College and

Research Institute, Mysuru, Karnataka, India

Received: 08 March 2018

Accepted: 03 April 2018

\section{*Correspondence to:}

Dr. Hemanth Kumar K. H., Email: 2011hemanth@ gmail.com

Copyright: (C) the author(s), publisher and licensee Medip Academy. This is an openaccess article distributed under the terms of the Creative Commons Attribution NonCommercial License, which permits unrestricted noncommercial use, distribution, and reproduction in any medium, provided the original work is properly cited.

\begin{abstract}
Background: Pharmacovigilance and adverse drug reactions monitoring has become an integral part to ensure patient safety. Targeting the younger doctors for sensitization towards pharmacovigilance is the key to ensure practice of ADR reporting in clinical practice. The objective of the study is to understand and assess the knowledge and perception of students towards pharmacovigilance and adverse drug reactions reporting.

Methods: The study included undergraduate medical students of second, prefinal and final years of Mysore Medical College. A validated and standardized KAP based questionnaire was distributed to all students. Willingness to answer and complete the questionnaire was considered as consent.

Results: The questions were statistically analysed individually and compared. Q1-Q10 compared knowledge towards pharmacovigilance, Q11-Q20 on the attitude and Q21-Q23 on the practice of ADR reporting. 325 questionnaires were distributed of which only 280 consented (second year - 114, pre-final - 98, final 68). $112(49.1 \%), 137(69.9 \%)$ and $79(58.1 \%)$ of the three groups respectively knew what pharmacovigilance and ADR is. 79.8\%, 76.5\% and 75\% knew who can report ADRs while $18.4 \%, 32.7 \%$ and $33.8 \%$ did not know what ADRs to report. 73(64.1\%); 93(81.6\%), 18(18.4\%); 69(70.4\%), 13(19.1\%); 37(54.4\%) knew the existence of AMC in the institute and the PvPI respectively. More than $92 \%$ agreed that ADR reporting is necessary. Majority (>90\%) agreed that PV and ADR reporting should be taught to all health care students while $28 \%, 30 \%$ and $54 \%$ said that it was not well covered in their curriculum.73(64\%), 51(52\%) and 63(93\%) were not familiar with the ADR reporting form.

Conclusions: Pharmacovigilance and ADR reporting needs to be made compulsory, have better, interesting ways to learn and understand it, so that the students can practice it with confidence in their clinical practice.
\end{abstract}

Keywords: Adverse Drug Reactions, Attitude and Practice (KAP), Knowledge, Pharmacovigilance, PvPI

\section{INTRODUCTION}

No Drug is "Absolutely Safe", every drug is only Relatively Safe. Modern medicines have revolutionised and changed the way of disease treatment. But, in spite of this change, the adverse drug reactions (ADR) continue to be one of the most important major problems associated with the use of drug therapy. The World Health Organisation (WHO) defines an adverse drug reaction as "any response to a drug that is noxious and unintended and that occurs at doses used in humans for prophylaxis, diagnosis or therapy of disease as for the modification of 
physiological function, excluding failure to accomplish the intended purpose". ${ }^{1}$ ADRs are responsible for about $0.3 \%$ to $11 \%$ of hospital admissions globally. ${ }^{2}$ ADRs affect both children as well as adults and can cause illness, increased number of hospital admissions and casualty visits, prolong hospital stay, lead to disability and even death. ${ }^{3-6}$ ADRs ranks among the top 10 causes for patient mortality globally. Over 2 million serious cases due to ADRs are seen per year globally. The incidence of serious ADRs in India is said to be around $6.7 \% .^{7}$ Economically, the amount spent to treat and manage these ADRs are remarkable. ADRs are a huge economic burden to the society which affects and derails the health care system. ${ }^{8}$ On an average the United States spends up to 30 billion US dollars towards management of ADRs. Thus, it becomes important to minimize and prevent harm to patients with the use of these drugs and make sure that the ADRs are detected even before they are manifested clinically. Adverse drug reactions are thus and have become a major public health concern. So, monitoring and prevention of ADRs becomes vital for ensuring absolute patient safety. Pharmacovigilance is a part of patient care that ensure the best use drugs, to prevent and treat adverse drug reactions. ${ }^{9}$ According to World Health Organisation (WHO), pharmacovigilance is "the science and activities related to the detection, assessment, understanding and prevention of adverse events or any other drug related problem". ${ }^{10,11}$

The World Health Organisation through the global Pharmacovigilance programme and its Uppsala Monitoring Centre (WHO-UMC), Sweden is responsible for maintaining the international database of all the adverse drug reaction reports received from all over the globe from different nations. ${ }^{12}$ But, however it is estimated that only $6-10 \%$ of the total ADRs are reported globally. ${ }^{13}$ India too functions and participates under the WHO-UMC, through the Pharmacovigilance Programme of India (PvPI), established in 2009 and coordinated by the National Co-Ordinating Centre, Indian Pharmacopeia Commission (NCC-IPC) situated at Ghaziabad, Uttar Pradesh, with the various Adverse Drug Monitoring Centres (AMC) nationwide. But, the contribution of India towards the international ADR database is a mere $2 \% .^{14}$ The main reason for this under reporting may be due to the lack of adequate knowledge and more importantly the lack of regular sensitization programmes for the health care professionals towards ADR reporting. ${ }^{15}$ The PvPI used to function with only 22 AMCs but now more than 150 AMCs are present nationwide. ${ }^{16}$ The AMC at Mysore Medical College and Research Institute and associated hospitals was established and has been functioning since November 2016.

The best method to report and monitor ADRs is the active reporting of ICSRs (Individual Case Safety Report), where the practicing clinician or any health care professional reports the ADR seen during clinical practice. ${ }^{17}$ But, even with constant sensitization the number of ICSRs through active reporting system remains less. So, we decided to target the undergraduate medical students of our very own institution, to understand the reason for the gap in under reporting by assessing their knowledge, attitude and practice towards pharmacovigilance, adverse drug reactions reporting and to ensure efficient functioning of the AMC at our institute. ${ }^{18-21}$

\section{METHODS}

The study was conducted at Mysore Medical College and Research Institute, a tertiary care teaching hospital and institute in Mysuru, a city in the South Indian state of Karnataka, India between the months of October and December 2017.

It was a questionnaire based cross sectional study aimed at assessing the knowledge, attitude and practice towards ADR reporting. The questionnaire was initially developed accordingly to meet the objectives of the study and after referring to various questionnaires used to assess the KAP (knowledge, attitude and practice) towards pharmacovigilance in other various studies performed within and outside India. The questionnaire was standardised and validated by the faculty members of the department of pharmacology, Mysore Medical College and Research Institute, with the necessary correction made and taken into consideration.

The target population of this study were the under graduate students of second year, pre-final year and final year, who were already exposed and familiar with adverse drug reactions and pharmacovigilance.

The standardised and validated questionnaires were distributed to all the students of second, pre-final and final year after obtaining approval from the Institutional Ethics Committee.

The students were explained about the questionnaire and the need for the study. The required instructions for answering the questionnaire was also explained. Willingness to answer the questionnaire was considered as informed consent, with the student signing on top of the questionnaire agreeing to consent to the study. 30 minutes was given for every participant to complete the questionnaire.

The questionnaire consisted of a total of 23 questions in all (Q1-Q23). The first 10 questions (Q1-Q10) assessed the knowledge towards pharmacovigilance with multiple options and only one single correct option. The next 10 questions (Q11-Q20) were directed to understand the attitude of the students towards pharmacovigilance. These carried a 5 point Likert scale format - Strongly Agree, Agree, Neutral/No Comment, Disagree and Strongly Disagree.

The final 3 questions (Q21, Q22, A23) were related to the practice of ADR reporting and assessed if they had witnessed an ADR, seen an ADR reporting form and if they had identified/discussed/reported an ADR. 
All the distributed questionnaires were collected. Unfilled, incomplete questionnaires were excluded from the study. Only those questionnaires which had all 24 questions answered were included and subjected for statistical analysis. SPSS version 20 was adopted for descriptive analysis, number and percentage, chi-square test, to test for statistical significance.

\section{RESULTS}

The questionnaires were distributed to 350 undergraduate medical students belonging to either second year, pre-final or final year. Among these, only 280 consented and completely filled the questionnaires, of which 114 were second year students, 98 were pre-final year students and 68 were final year students. The distribution of student involvement is depicted in Figure 1.

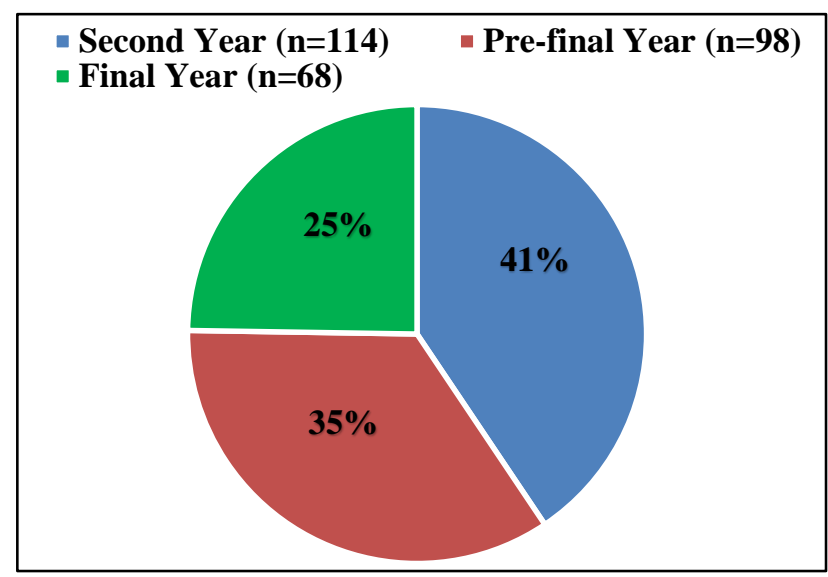

Figure 1: Distribution of student involvement in the study.

\section{Analysis of knowledge}

The results of the knowledge based questions are shown in Table 1. Of the 280 who were included in the study only $59.6 \%[58(50.9 \%), 71(72.4 \%), 38(55.9 \%)]$ of the responders knew what Pharmacovigilance is (Figure 2).

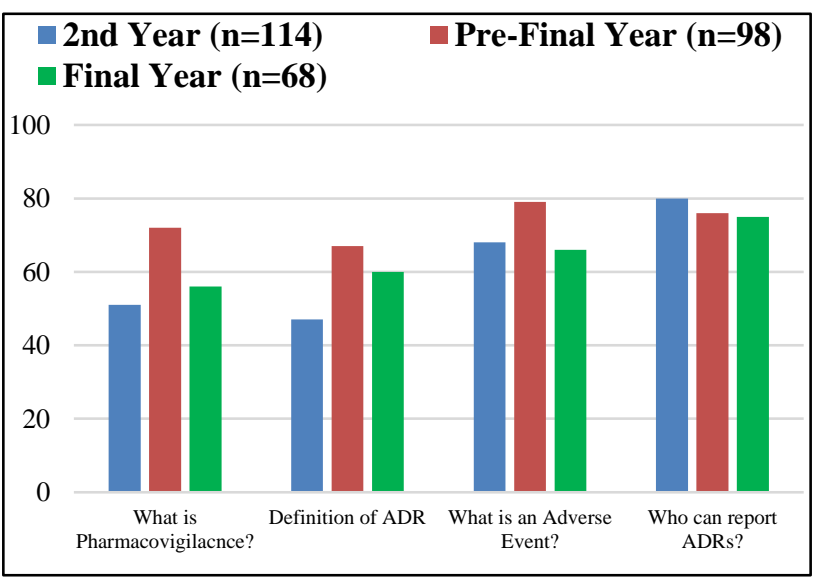

Figure 2: Knowledge of pharmacovigilance and Adverse Drug Reactions - I.
Table 1: Correct response towards Knowledge of pharmacovigilance and ADR reporting aonf medical undergraduate students.

\begin{tabular}{|c|c|c|c|c|}
\hline Question & $\begin{array}{l}\text { Second } \\
\text { year } \mathbf{N} \\
(\%)\end{array}$ & $\begin{array}{l}\text { Pre- } \\
\text { final } \\
\text { year } n \\
(\%)\end{array}$ & $\begin{array}{l}\text { Final } \\
\text { year } \mathbf{N} \\
(\%)\end{array}$ & $\begin{array}{l}\text { Statistical } \\
\text { significance } \\
\text { (p value) }\end{array}$ \\
\hline $\begin{array}{l}\text { What is } \\
\text { Pharmacovi } \\
\text { gilance? }\end{array}$ & $\begin{array}{l}58 \\
(50.9 \%)\end{array}$ & $\begin{array}{l}71 \\
(72.4 \%)\end{array}$ & $\begin{array}{l}38 \\
(55.9 \%)\end{array}$ & $\begin{array}{l}0.005 \\
(p<0.05)\end{array}$ \\
\hline $\begin{array}{l}\text { Definition } \\
\text { of an ADR }\end{array}$ & $\begin{array}{l}54 \\
(47.4 \%) \\
\end{array}$ & $\begin{array}{l}66 \\
(67.3 \%) \\
\end{array}$ & $\begin{array}{l}41 \\
(60.3 \%)\end{array}$ & $\begin{array}{l}0.012 \\
(p<0.05)\end{array}$ \\
\hline $\begin{array}{l}\text { What is an } \\
\text { Adverse } \\
\text { Event? }\end{array}$ & $\begin{array}{l}77 \\
(67.5 \%)\end{array}$ & $\begin{array}{l}77 \\
(78.6 \%)\end{array}$ & $\begin{array}{l}45 \\
(66.2 \%)\end{array}$ & \\
\hline $\begin{array}{l}\text { Who can } \\
\text { report } \\
\text { ADRs? }\end{array}$ & $\begin{array}{l}91 \\
(79.8 \%)\end{array}$ & $\begin{array}{l}75 \\
(76.5 \%)\end{array}$ & $51(75 \%)$ & \\
\hline $\begin{array}{l}\text { Location of } \\
\text { WHO- } \\
\text { UMC? }\end{array}$ & $\begin{array}{l}62 \\
(54.4 \%)\end{array}$ & $\begin{array}{l}24 \\
(24.5 \%)\end{array}$ & $\begin{array}{l}14 \\
(20.6 \%)\end{array}$ & $\begin{array}{l}0.000 \\
(p<0.05)\end{array}$ \\
\hline $\begin{array}{l}\text { Presence of } \\
\text { ADR } \\
\text { Monitoring } \\
\text { Centre in } \\
\text { the } \\
\text { institution? }\end{array}$ & $\begin{array}{l}73 \\
(64 \%)\end{array}$ & $\begin{array}{l}18 \\
(18.4 \%)\end{array}$ & $\begin{array}{l}13 \\
(19.1 \%)\end{array}$ & $\begin{array}{l}0.000 \\
(\mathrm{p}<0.05)\end{array}$ \\
\hline $\begin{array}{l}\text { What type } \\
\text { of ADRs } \\
\text { should be } \\
\text { reported? }\end{array}$ & $\begin{array}{l}93 \\
(81.6 \%)\end{array}$ & $\begin{array}{l}66 \\
(67.3 \%)\end{array}$ & $\begin{array}{l}45 \\
(66.2 \%)\end{array}$ & $\begin{array}{l}0.024 \\
(\mathrm{p}<0.05)\end{array}$ \\
\hline $\begin{array}{l}\text { Which scale } \\
\text { is } \\
\text { commonly } \\
\text { used to } \\
\text { assess } \\
\text { causality of } \\
\text { an ADR? }\end{array}$ & $\begin{array}{l}30 \\
(26.3 \%)\end{array}$ & $\begin{array}{l}30 \\
(30.6 \%)\end{array}$ & $\begin{array}{l}14 \\
(20.6 \%)\end{array}$ & \\
\hline $\begin{array}{l}\text { What is a } \\
\text { serious } \\
\text { Adverse } \\
\text { event? }\end{array}$ & $\begin{array}{l}67 \\
(58.8 \%)\end{array}$ & $\begin{array}{l}80 \\
(81.6 \%)\end{array}$ & $45(66.2 \%)$ & $\begin{array}{l}0.001 \\
(0<0.05)\end{array}$ \\
\hline $\begin{array}{l}\text { Presence of } \\
\text { an existing } \\
\text { Pharmacovi } \\
\text { gilance } \\
\text { Programme } \\
\text { of India } \\
\text { (PvPI)? }\end{array}$ & $\begin{array}{l}93 \\
(81.6 \%)\end{array}$ & $\begin{array}{l}69 \\
(70.4 \% 0\end{array}$ & $\begin{array}{l}37 \\
(54.4 \%)\end{array}$ & $\begin{array}{l}0.000 \\
(\mathrm{p}<0.05)\end{array}$ \\
\hline
\end{tabular}

The pre-final year students seemed to know the actual definition of an adverse drug reaction than the other two groups with the result found to be statistically significant $(\mathrm{p}=0.012)$. Almost more than two-thirds (average - 77.5\%, 217 out of 280) were aware of who can report ADRs. $71.1 \%$ (199) of the responders knew about the existence of the Pharmacovigilance Programme of India (PvPI) but only very little proportion, $35.7 \%(54.4 \%, 24.5 \%, 20.6 \%)$ and $37.1 \%(64 \%, 18.4 \%, 19.1 \%)$ knew the location of WHO-UMC and the presence of AMC in the institute respectively (Figure 3). 


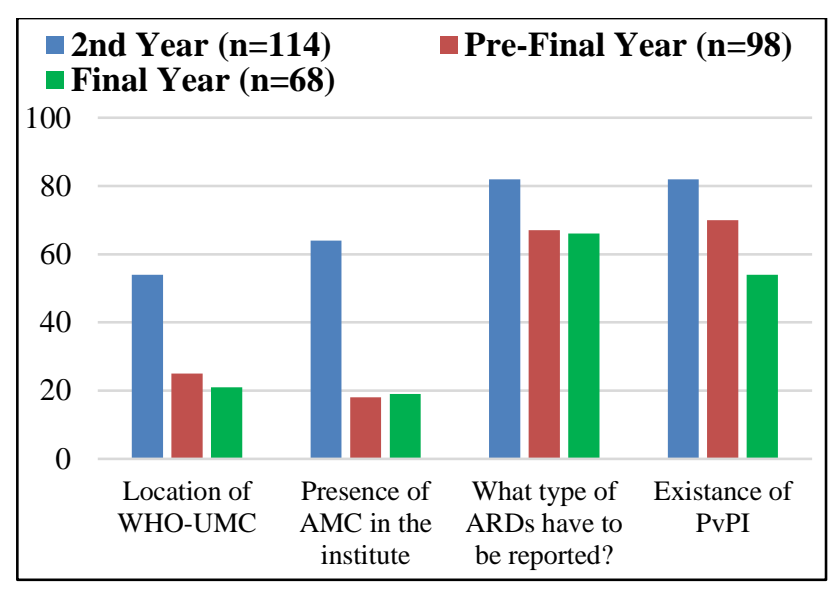

Figure 3: Knowledge towards pharmacovigilance and Adverse Drug Reactions - II.
The decrease in number in the pre-final and final year group was probably because of the reason that the AMC in this institute was established in November 2016 and so, when ADR and PV was taught to them during their second year of medicine, it had not been established, suggesting that the knowledge of the students to be good.

The total knowledge (Table 2) among the entire responders showed a mean of $6.16 \pm 1.86$ overall. The average mean of the total knowledge among the three groups was $6.37 \pm 1.90,6.35 \pm 1.78$ and $5.54 \pm 1.80$ respectively in the three groups of student population.

The overall knowledge of the groups showed to be closer to almost $70 \%$ of the included target population but seemed better among the second years $(p=0.007)$ and shows a decline in the pre-final and final year students.

Table 2: Total knowledge of medical undergraduate students.

\begin{tabular}{|ll|llll|}
\hline Year & No. of participants $(\mathbf{N})$ & Mean & Standard deviation & Minimum score & Maximum score \\
\hline $2^{\text {nd }}$ year & 114 & 6.3684 & 1.90139 & 2.00 & 10.00 \\
\hline Pre-Final year & 98 & 6.3469 & 1.78252 & 3.00 & 11.00 \\
\hline Final year & 68 & 5.5441 & 1.79912 & 1.00 & 10.00 \\
\hline Overall & 280 & 6.1607 & 1.86245 & 1.00 & 10.00 \\
\hline
\end{tabular}

\section{Analysis of attitude}

Table 3 shows the overall attitude of the undergraduate students towards pharmacovigilance and ADR reporting. 95\% (266 of 280) of the participants totally agreed (agree plus strongly agree) that ADR reporting is necessary with 99\% (97) of the pre-final years agreeing towards the need to report ADR as compared to $93 \%$ and $92.3 \%$ in the second and final year students groups.

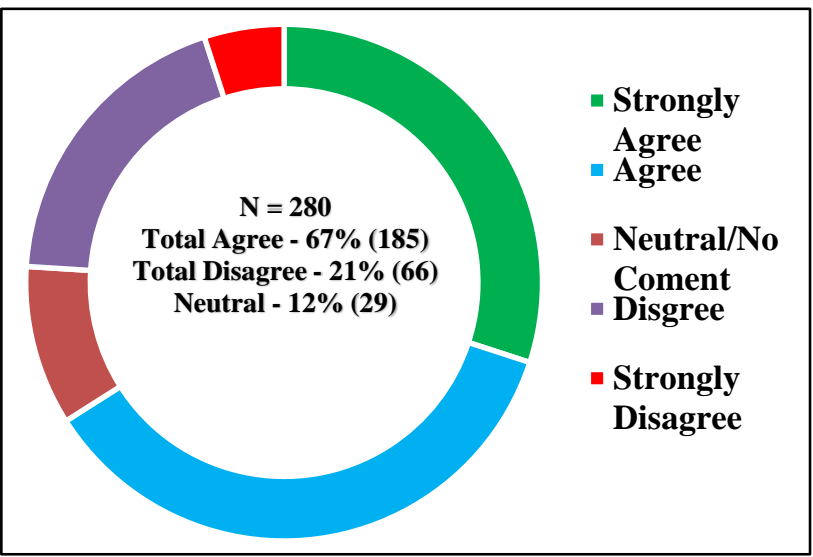

Figure 4: Overall attitude of students towards ADR reporting to be a professional obligation.

But, only $66 \%$ (185) of the participants supported that reporting of ADRs to be a professional obligation, with
$11 \%$ having no views regarding the question and about one-third of the responders disagreeing to it (Figure 4). 222 (79.3\%) of the participants totally agreed that the ADR reporting should be voluntary with the pre-final year students showing a better positive attitude (86.8\%) as compared to the other two groups of students $(74.6 \%$ and $76.4 \%$ ). $232(82.9 \%)$ of the responders felt that the ADR reporting should be made compulsory and 20(7.15\%) were of the view that ADR reporting will not ensure patient safety and make no difference.

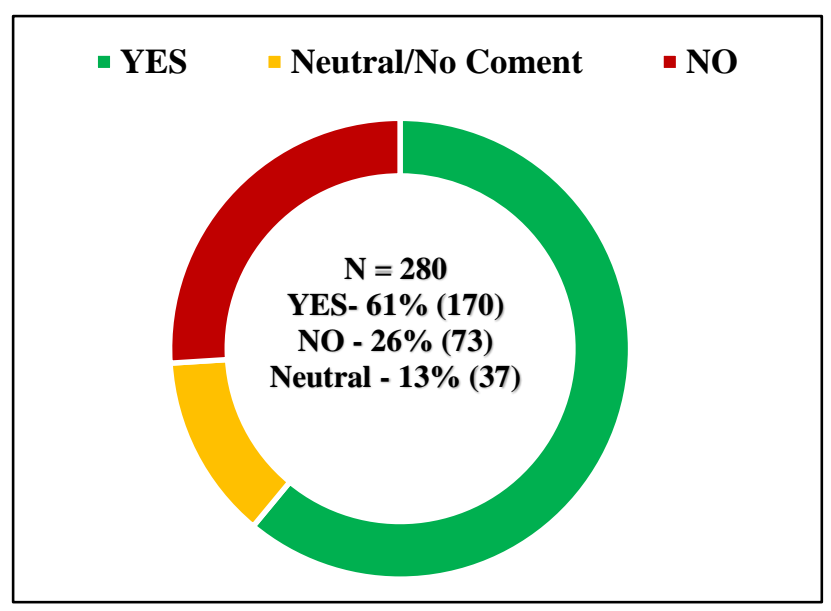

Figure 5: Overall response towards Pharmacovigilance being covered well in the undergraduate curriculum. 
About $95 \%$ of the responders were of the view that pharmacovigilance and ADR reporting should be taught to all health care professionals (HCP). Interestingly, 110 students felt that pharmacovigilance and adverse drug reactions, reporting and monitoring was not covered well in their curriculum. Figure 5 shows that almost $75 \%$ (48 students) in final year group said that PV was not covered well as compared to $28 \%$ and $29.5 \%$ among the second and pre-final year students.

The overall attitude of the students is positive, reveals that they are interested in understanding the need for pharmacovigilance and to practice ADR reporting.

Table 3: Overall attitude of medical undergraduate students towards pharmacovigilance and ADR reporting.

\begin{tabular}{|c|c|c|c|c|c|}
\hline Question & $\begin{array}{l}\text { Strongly } \\
\text { agree }\end{array}$ & Agree & $\begin{array}{l}\text { No comment/ } \\
\text { neutral }\end{array}$ & Disagree & $\begin{array}{l}\text { Strongly } \\
\text { disagree }\end{array}$ \\
\hline ADR reporting is necessary & $\begin{array}{l}203 \\
(72.5 \%)\end{array}$ & $63(22.5 \%)$ & $2(0.7 \%)$ & $6(2.1 \%)$ & $6(2.1 \%)$ \\
\hline Is ADR reporting a professional obligation? & $\begin{array}{l}83 \\
(29.6 \%)\end{array}$ & $\begin{array}{l}102 \\
(36.4 \%)\end{array}$ & $29(10.4 \%)$ & $\begin{array}{l}52 \\
(18.6 \%)\end{array}$ & $14(5 \%)$ \\
\hline $\begin{array}{l}\text { Is it necessary to confirm that the ADR is related } \\
\text { to a particular drug before reporting? }\end{array}$ & $\begin{array}{l}110 \\
(39.3 \%)\end{array}$ & $\begin{array}{l}124 \\
(44.3 \%)\end{array}$ & $16(5.7 \%)$ & $26(9.3 \%)$ & $4(1.4 \%)$ \\
\hline ADR reporting should be voluntary & $\begin{array}{l}80 \\
(28.6 \%)\end{array}$ & $\begin{array}{l}142 \\
(50.7 \%)\end{array}$ & $13(4.6 \%)$ & $\begin{array}{l}39(13.9 \\
\%)\end{array}$ & $\begin{array}{l}6(2.1 \\
\%)\end{array}$ \\
\hline ADR reporting must be made compulsory & $\begin{array}{l}91 \\
(32.5 \%)\end{array}$ & $\begin{array}{l}141 \\
(50.4 \%)\end{array}$ & $27(9.6 \%)$ & $18(6.4 \%)$ & $3(1.1 \%)$ \\
\hline $\begin{array}{l}\text { Only serious and unexpected reactions be } \\
\text { reported }\end{array}$ & $\begin{array}{l}29 \\
(10.4 \%)\end{array}$ & $68(24.3 \%)$ & $15(5.4 \%)$ & $\begin{array}{l}134 \\
(47.9 \%)\end{array}$ & $\begin{array}{l}34 \\
(12.1 \%)\end{array}$ \\
\hline $\begin{array}{l}\text { Pharmacovigilance should be taught to all health } \\
\text { care professionals }\end{array}$ & $\begin{array}{l}143 \\
(51.1 \%)\end{array}$ & $\begin{array}{l}122 \\
(43.6 \%)\end{array}$ & $9(3.2 \%)$ & $5(1.8 \%)$ & $1(0.4 \%)$ \\
\hline $\begin{array}{l}\text { Pharmacovigilance is well covered in the } \\
\text { undergraduate curriculum }\end{array}$ & $\begin{array}{l}31 \\
(11.1 \%)\end{array}$ & $\begin{array}{l}139 \\
(49.6 \%)\end{array}$ & $37(13.2 \%)$ & $\begin{array}{l}61 \\
(21.8 \%)\end{array}$ & $\begin{array}{l}12 \\
(4.3 \%)\end{array}$ \\
\hline $\begin{array}{l}\text { ADR can be better learnt during } \\
\text { internship/clinical postings }\end{array}$ & $\begin{array}{l}53 \\
(18.9 \%)\end{array}$ & $\begin{array}{l}158 \\
(56.4 \%)\end{array}$ & $26(9.3 \%)$ & $35(12.5 \%)$ & $8) 2.9 \%)$ \\
\hline ADR reporting will ensure patient safety & $\begin{array}{l}149 \\
(53.2 \%)\end{array}$ & $\begin{array}{l}111 \\
(39.6 \%)\end{array}$ & $10(3.6 \%)$ & $9(3.2 \%)$ & $1(0.4 \%)$ \\
\hline
\end{tabular}

\section{Analysis of practice towards $A D R$ reporting}

This section consisted of only three questions and targeted if the student ever practiced reporting ADRs that were identified by them during their clinical postings (Figure 6).

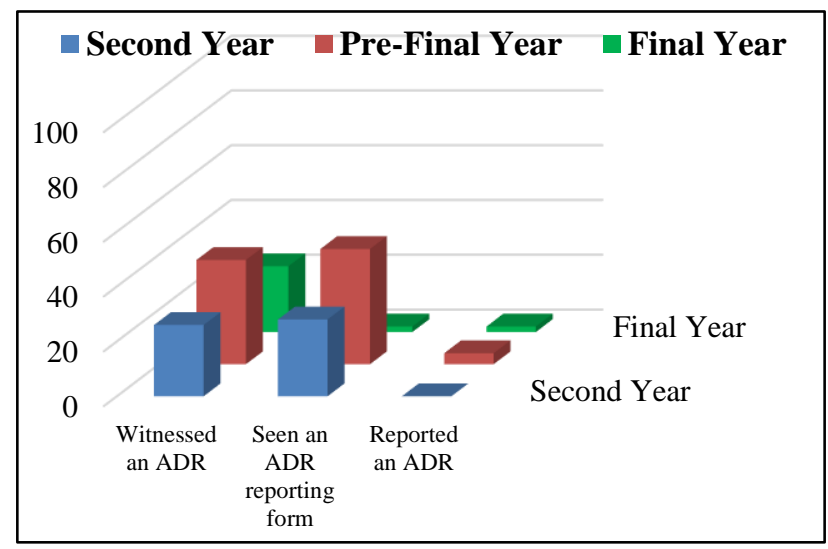

Figure 6: Practice of Adverse Drug Reactions reporting among medical undergraduate students.
Table 4: Practice of medical undergraduate students towards ADR reporting.

\begin{tabular}{|c|c|c|c|c|}
\hline Question & Response & $\begin{array}{l}\text { Second } \\
\text { year } \mathbf{N} \\
(\%)\end{array}$ & $\begin{array}{l}\text { Pre- } \\
\text { final } \\
\text { year } \mathbf{N} \\
(\%)\end{array}$ & $\begin{array}{l}\text { Final } \\
\text { year N } \\
(\%)\end{array}$ \\
\hline \multirow{2}{*}{$\begin{array}{l}\text { Have you } \\
\text { witnessed } \\
\text { an ADR? }\end{array}$} & Yes & $\begin{array}{l}30 \\
(26.3 \%)\end{array}$ & $\begin{array}{l}37 \\
(37.8 \%)\end{array}$ & $\begin{array}{l}16 \\
(23.5 \%)\end{array}$ \\
\hline & No & $\begin{array}{l}84 \\
(73.7 \%)\end{array}$ & $\begin{array}{l}61 \\
(62.2 \%)\end{array}$ & $\begin{array}{l}52 \\
(76.5 \%)\end{array}$ \\
\hline \multirow{2}{*}{$\begin{array}{l}\text { Have you } \\
\text { seen an } \\
\text { ADR } \\
\text { reporting } \\
\text { form? }\end{array}$} & Yes & $\begin{array}{l}33 \\
(28.9 \%)\end{array}$ & $\begin{array}{l}41 \\
(41.8 \%)\end{array}$ & $\begin{array}{l}1 \\
(1.5 \%)\end{array}$ \\
\hline & No & $\begin{array}{l}81 \\
(71.1 \%)\end{array}$ & $\begin{array}{l}57 \\
(48.2 \%)\end{array}$ & $\begin{array}{l}67 \\
(98.5 \%)\end{array}$ \\
\hline \multirow[b]{2}{*}{$\begin{array}{l}\text { Have you } \\
\text { reported an } \\
\text { ADR or } \\
\text { have you } \\
\text { filled an } \\
\text { ADR } \\
\text { reporting } \\
\text { form? }\end{array}$} & Yes & $0(0 \%)$ & $4(4.1 \%)$ & $1(1.5 \%)$ \\
\hline & No & $\begin{array}{l}114 \\
(100 \%)\end{array}$ & $\begin{array}{l}94 \\
(95.9 \%)\end{array}$ & $\begin{array}{l}67 \\
(98.5 \%)\end{array}$ \\
\hline
\end{tabular}


Table 4 shows the practice of second, pre-final and final year medical students towards ADR reporting. About onethird of the total responders said that they had witnessed an ADR (Q21) in their clinical postings but only 75 out of 280 had seen an ADR form. Of which 41 students were from the pre-final years and 33 from the second year. Only 1 student from the final year said that he had seen an ADR reporting form (Q22). Of the 41 and 33, none and 4 students had reported an ADR, and the only one student in the final year group who had seen the ADR form had reported an ADR (Q23). Reporting here does not only mean reporting to the AMC, but also identifying an ADR and discussing with the residents/staff regarding the ADR.

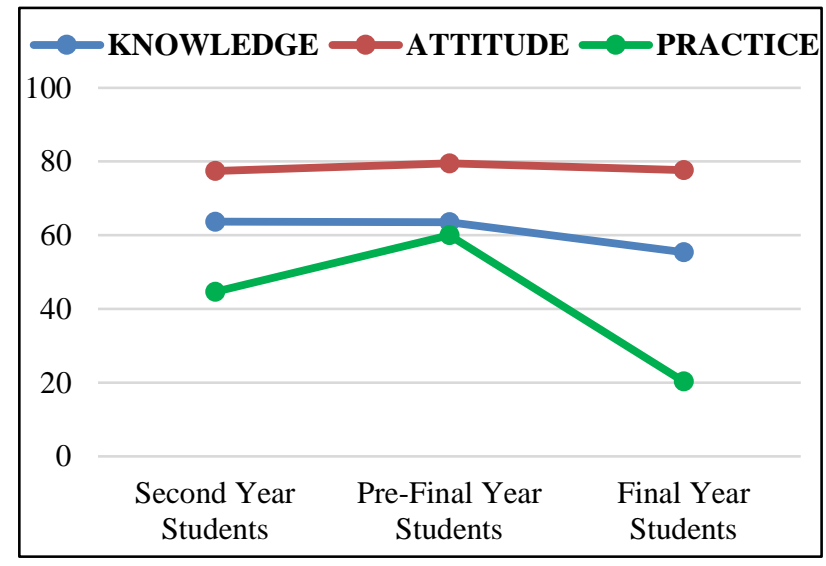

Figure 7: Overall KAP of undergraduate students towards pharmacovigilance.

\section{DISCUSSION}

Pharmacovigilance and ADR reporting has become an important tool to assess drug safety and ensure patient safety. Active reporting of ADRs is the most important requirement for a good pharmacovigilance program, but underreporting is a major concern for the pharmacovigilance programme of India (PvPI). A number of studies have been done on health care professionals to assess the KAP towards pharmacovigilance but very few among the medical undergraduates and postgraduates. ${ }^{16,18-21}$

The previous studies done, concluded that the main reason for underreporting and decreased practice was the lack of knowledge towards pharmacovigilance among health care professionals. ${ }^{18-21}$ So, authors decided to target the source of the knowledge problem, the younger professionals in the undergraduate medical students to have better understanding of the reasons for decreased practice of ADR reporting among doctors. This current study investigates and assesses the knowledge, attitude towards pharmacovigilance and practice of adverse drug reactions reporting among medical undergraduate (second, pre-final and final) students.

The present study shows that the knowledge and attitude towards pharmacovigilance is fairly good overall among the medical students as compared to the previous similar studies, but what is important to know is that there is a decrease in the interest towards ADR reporting (as shown by the number of students willing to participate to a pharmacovigilance questionnaire study) and decline in the knowledge (total knowledge score - $6.37 \pm 1.90$ vs $6.35 \pm 1.78$ vs $5.54 \pm 1.79$ in the three groups respectively, Table 2) and positive attitude overall towards pharmacovigilance and ADR reporting (Figure 2, Figure 3). ${ }^{16,18-21}$ This could be because of the fact that pharmacovigilance is included only in the curriculum of pharmacology which is a part of second year only and nothing related to ADR is included in the pre-final and final year.

Regarding decreased practice, it is probably because ADR reporting has not been made compulsory to the student in their undergraduate curriculum. On a positive note, there were 4 students who detected and reported ADR in the prefinal year group. This was because more emphasis was laid by the department of pharmacology in making them understand the importance of pharmacovigilance by having extra practical demonstrations, case studies and group tasks related to adverse drug reactions, which could not be covered for the present final year students and has not yet been implemented for the second year students.

The lack of knowledge and awareness of pharmacovigilance, ADR reporting, absence of pharmacovigilance in the undergraduate curriculum has been addressed with increased number of hours dedicated towards it both theoretically and practically, which has been reflected with increased numbers as compared to the previous studies.

The decline in knowledge and positive attitude needs to be addressed as it is significant for the undergraduate student to be motivated to report ADRs as an intern, post graduate resident or a consultant doctor in his/her future. Sensitizing and inserting positive attitude in the early career of a medical student would probably help in improving the current status of reporting in India. This can be attained by dedicating more hours towards pharmacovigilance, including it throughout the entire medical curriculum and not just restricting to pharmacology and second year of medical under graduation. Positive attitude and increased interest can be stimulated by having group task activities, hands on workshops and other better means of teaching pharmacovigilance to the students.

Further, the success of the program would be reflected by including the interns (previously included undergraduates) as well as postgraduate medical students in an extended study and assess the knowledge, attitude and practice among them.

Finally, from the study we can conclude that the overall knowledge and attitude is definitely better among the undergraduate students. The practice of pharmacovigilance and $\mathrm{ADR}$ reporting has to improve, 
and it can be done so by including pharmacovigilance throughout the entire course of medical curriculum and incorporating better, efficient and interesting methods to teach, sensitize and practice pharmacovigilance.

\section{ACKNOWLEDGEMENTS}

Authors would like to thank all the undergraduate students for their time support and co-operation. Authors also thank the Department of Pharmacology and the Mysore Medical College institute for their co-operation and permitting them to perform this study with ease.

\section{Funding: No funding sources}

Conflict of interest: None declared

Ethical approval: The study was approved by the Institutional Ethics Committee of Mysore Medical College and Research Institute and associated Hospitals, Mysuru, India

\section{REFERENCES}

1. Lee A, Thomas SHL. Adverse drug reactions. In: Walker R and Edward C. Clinical Pharmacy and Therapeutics, $3^{\text {rd }}$ Edition. US; Churchill Livingstone; 2003:33-46.

2. World Health Organization. Safety of Medicines: A Guide to Detecting and Reporting Adverse Drug Reactions. Geneva: WHO/EDM/QSM/2002.2;2002.

3. Lacoste-Roussillon C, Pouyanne P, Haramburu F, Miremont G, Begaud B. Incidence of serious adverse drug reactions in general practice: A prospective study. Clin Pharmacol Ther. 2001;69:458-62.

4. Classen DC, Pestonik SL, Evans RS, Lioyd JF, Burke JP. Adverse drug events in hospitalized patient- excess length of stay, extra cost and attributable mortality. JAMA. 1997;277:301-6.

5. Lazarou J, Pomeranz BH, Corey PN. Incidence of adverse reactions in hospitalized patients. A metaanalysis of prospective studies. JAMA. 1998;279:1200-5.

6. Pirmohamed M, James S, Meakin S, Green C, Scott AK. Adverse drug reactions as cause of admission to hospital: prospective analysis of 18820 patients. $\mathrm{Br}$ Med J. 2004;329:15-9.

7. Geer MI, Koul PA, Tanki SA, Shah MY. Frequency, types, severity, preventability and costs of Adverse Drug Reactions at a tertiary care hospital. J Pharmacol Toxicol Methods. 2016 Sep-Oct;81:323-34.

8. ASHP guidelines an adverse drug reaction monitoring and reporting. Am J Health Syst Pharm. 1995;52:1402.

9. Aziz Z, Siang TC, Badarudin NS. Reporting of adverse drug reactions: predictors of under-reporting in Malaysia. Pharmacoepidemiol Drug Saf. 2007; 16:223-8.

10. Conforti A, Costantini D, Zanetti F, Moretti U, Grezzana M, Leone R. Adverse drug reactions in older patients: an Italian observational prospective hospital study. Drug Healthc. Patient Saf. 2012;4:75-80.

11. Posthumus AA, Alingh CC, Zwaan CC. Adverse drug reaction-related admissions in paediatrics, a prospective singlecentre study. BMJ Open. 2012.

12. Protocol of National Pharmacovigilance Programme, November 2004. CDSCO, Ministry of Health and Family Welfare, Government of India. November, 2004. Available at: http://www.cdsco.nic.in/html/Pharmacovigilance\%20 protocol\%20.pdf

13. Feely J, Moriarty S, O'Connor P. Stimulating reporting of adverse drug reaction by using a fee. Br Med J. 1990;300:22-3.

14. Smith CC, Bennett PM, Pearce HM, Harrison PI, Reynolds DJM, Aronson JK, et al. Adverse drug reactions in a hospital general medical unit meriting notification to the Committee on Safety of Medicines. Br J Clin Pharmacol. 1996;42:423-9.

15. Tandon VR, Mahajan V, Khajuria V, Gullani Z. Under-reporting of adverse drug reactions: $A$ challenge for pharmacovigilance in India. Indian $\mathrm{J}$ Pharmacol. 2015;47(1):65-71.

16. Meher BR, Joshua N, Asha B, Mukherji D. A questionnaire based study to assess knowledge, attitude and practice of Pharmacovigilance among undergraduate medical students in a Tertiary Care Teaching Hospital of South India. Perspect Clin Res. 2015;6:217-21.

17. Ratan JL, Mangala L. An update on the Pharmacovigilance Programme of India. Front Pharmacol. 2015;6:194. Available at: https://www.researchgate.net/publication/282513881

18. Sivadasan S, Chyi NW, Ching AL, Ali AN, Veerasamy R, Marimuthub K, et al. Knowledge and perception towards pharmacovigilance and adverse drug reaction reporting among medicine and pharmacy students. World J Pharm Pharm Sci. 2014 Jan 8;3(3):1652-76.

19. Komaran and Dhar, A study on assessment of Knowledge, attitude and practice regarding pharmacovigilance among healthcare professionals in a tertiary care hospital, Andra Pradesh Int J Pharm Sci Res. 2016;7(12):5082-87.

20. Dhananjay K, Himasri E. A study of assessing knowledge, attitude, and practice pharmacovigilance among medical students of a South Indian teaching hospital. Int J Basic Clin Pharmacol. 2017;6(1):43-7.

21. Arjun TN, Sudhir H, GourahaA JS, Chavan K, Dayma A. Assessment of knowledge, attitude and practice related to pharmacovigilance among the healthcare professionals in a teaching hospital in central india: a questionnaire study. WJPPS. 2015 Jan 17;4(4):78599.

Cite this article as: Akshay JK, Kumar HKH.

Knowledge and perception towards

pharmacovigilance and adverse drug reactions reporting among medical students at a teaching hospital in South India. Int J Basic Clin Pharmacol 2018;7:866-72. 